Available online at GSC Online Press Directory

GSC Biological and Pharmaceutical Sciences

e-ISSN: 2581-3250, CODEN (USA): GBPSC2

Journal homepage: https://www.gsconlinepress.com/journals/gscbps

(RESEARCH ARTICLE)

\title{
Comparative evaluation of the phytochemical, proximate and mineral quality of Nigerian Capsicum annum exposed to open and solar drying
}

\author{
Tambuwal Amamatu Dahiru 1, Okoh Ezennia Valentine Charles ${ }^{1}$, Ogbiko Cyril 1, ${ }^{*}$ and Maishanu Muhammad \\ Saidu ${ }^{2}$
}

${ }^{1}$ Department of Pure and Applied Chemistry, Faculty of Science, Usmanu Danfodiyo University Sokoto, Nigeria.

${ }^{2}$ Sokoto Energy Research Centre, Energy Commission of Nigeria.

Publication history: Received on 01 November 2018; revised on 27 November 2018; accepted on 28 November 2018

Article DOI: https://doi.org/10.30574/gscbps.2018.5.2.0128

\begin{abstract}
The study investigated the comparative evaluation of proximate, phytochemical, and elemental quality of Capsicum annum pepper variety. The pepper variety was purchased fresh from local market in Sokoto, Sokoto State Nigeria. The samples were washed thoroughly with distilled water, thinly sliced and sorted into three treatment groups, two of which were subjected to open sun and solar drying methods for 3 weeks and $60{ }^{\circ} \mathrm{C}$ for 24 hours respectively. The third was analyzed fresh and hence serves as the control. The dried samples were grounded with an electric blender, weighed and stored in properly labeled air-tight containers. The result of the analysis showed that the fresh sample contains a higher percentage of all the analyzed phytochemicals compared to those exposed to both drying methods. The proximate and elemental analysis of the samples subjected to the drying methods was higher compared to the fresh sample except for the moisture and carbohydrate contents. The result of this analysis revealed that the pepper variety have high nutritive value, medicinal value and can be used to remediate diseases and sustain health.
\end{abstract}

Keywords: Elemental composition; Pepper; Phytochemical; Proximate

\section{Introduction}

Capsicum annum popularly called red pepper, chili, or chili belongs to the family Solanaceae. The genus Capsicum represents a diverse plant group comprising of about twenty seven species with five namely Capsicum annuum, $C$. frutescens, Capsicum genus, Capsicum baccatum and Capsicum pubescens considered as the domesticated species while the other twenty two are un-domesticated [1]. Most agricultural products require drying to preserve the quality of the final product. Traditionally, red pepper is dried directly under the sun requiring an area with a large, open space and often takes long drying times resulting in low-quality products. It is highly dependent on the availability of sunshine and is susceptible to contamination with foreign materials and insect and fungal infestations, which thrive in moist conditions, rendering red pepper unusable [2]. As an alternative to open sun drying, solar drying is one of the most attractive and promising applications of solar energy systems now been proposed for extensive drying of agricultural products since they are environment-friendly technology and is economically viable in most developing countries for the drying of agricultural fruits and vegetables [3]. Nigeria has abundance of pepper varieties that are grown all year round since it occupies an important place in the diets of Nigerians. Red Pepper is an important agricultural crop, not only because of its economic importance, an important health-protecting factor by prevention of widespread human diseases but also due to nutritional and medicinal value. It is an excellent ingredient of all cooking and a rich source of natural colors and antioxidant compounds as well as vitamins $\mathrm{A}$ and $\mathrm{C}$, minerals, carotenoids, and phenolic compounds which are important source of nutrient in human diet [4-6]. The nutritional information on this variety of pepper will be useful for the nutritional education of the public as a means to improving the nutritional status of the population.

\footnotetext{
${ }^{*}$ Corresponding author

E-mail address: cyril.ogbiko@udusok.edu.ng
} 
Hence this study was aimed at determining the proximate, phytochemical and mineral quality of both open sun and solar dried Capsicum annum cultivated and consumed in Nigeria.

\section{Materials and methods}

\subsection{Sample collection}

Fresh samples of the Nigerian C. annuum also known as Tattasai in Hausa language in Northern Nigeria were obtained from Kasuwan Daji in Sokoto State Nigeria in June 2017. They were identified and authenticated at the Botany Unit, Department of Biological Sciences, Usmanu Danfodiyo University, Sokoto by a taxonomist with herbarium number UDUH/ANS/0066 issued.

\subsection{Preparation of sample}

The samples were washed with distilled water, thinly sliced and divided into three portions. They were all treated with chlorine concentrated solution. Two portions were dried using the open sun method for three weeks and the solar dryer designed by the Sokoto Energy Research Centre, Usmanu Danfodiyo University, Sokoto State, Nigeria operated at a temperature of $60{ }^{\circ} \mathrm{C}$ for 24 hours. The third portion which served as the control was analyzed fresh upon collection and after pretreatment. The dried samples were grounded with an electric blender, weighed and stored in properly labeled air-tight containers.

\subsection{Determination of phytochemicals}

The alkaloid, tannin and saponin contents were determined using the methods described by Maxwell et al., [7], Bohn and Kocai-Abyaza [8] and Makkar and Becker [9] respectively. The flavonoids, anthraquinones, and polyphenols contents were determined by the method of Trease and Evans [10].

\subsection{Determination of proximate analyses}

Moisture content, ash content, crude protein, crude fibre, crude lipid and total carbohydrates contents were determined by the procedure described by Lawal and Matazu [11] and Lawal and Dangoggo [12]. The carbohydrate content was determined by difference: $100-(\%$ Moisture $+\%$ Ash $+\%$ Protein $+\%$ Crude fibre $+\%$ Crude lipid). The moisture content was determined by hot air oven method at $105^{\circ} \mathrm{C}$. The Macro Kjeldahl method was used for the determination of protein content. The fat content was determined by extracting $2 \mathrm{~g}$ of sample with petroleum ether (boiling point of $40-60{ }^{\circ} \mathrm{C}$ ) using Soxhlet extraction method. Ash content was determined by weighing $2 \mathrm{~g}$ of dry sample into a tarred porcelain crucible which was incinerated at $550{ }^{\circ} \mathrm{C}$ in an ash muffle furnace until ash was obtained. The crude fiber was determined by exhaustive extraction of soluble substances in sample using $1.25 \% \mathrm{H}_{2} \mathrm{SO}_{4}$ acid and $1.25 \% \mathrm{NaOH}$ solution after the residue was ashed and the loss in weight was recorded as crude fiber. All determination was performed in triplicate in each case.

\subsection{Determination of mineral content}

The samples were wet digested with concentrated nitric and percholoric acids. The method of AOAC [13] was used to determine the calcium and magnesium levels in the sample where $1 \mathrm{~cm}^{3}$ of the clear supernatant was diluted with 19 $\mathrm{cm}^{3}$ of distilled water. $1 \mathrm{~cm}^{3}$ of $10 \% \mathrm{NaOH}$ and a drop of murexide indicator were added. The mixture was titrated with $0.01 \mathrm{M}$ EDTA solution and the colour changed from pink to purple at the end point. The calcium content was calculated using the expression:

$$
\text { Concentration of } \mathrm{Ca}\left(\frac{\mathrm{mg}}{100 \mathrm{~g}}\right)=\frac{\mathrm{TV} \times \mathrm{M} \text {. of EDTA } \times 1000}{\text { Aliquot taken }}
$$

Where: TV = Titre value; $\mathrm{M}=$ Molarity of EDTA and Aliquot = volume of sample solution taken.

The magnesium/calcium content was determined by EDTA titration where $1 \mathrm{~cm}^{3}$ of the clear supernatant was diluted with $19 \mathrm{~cm}^{3}$ distilled water. $5 \mathrm{~cm}^{3}$ of ammonium buffer solution and 1 drop of Erichrome black T indicator were added. The mixture was titrated with $0.01 \mathrm{M}$ EDTA solution and the colour changed from purple to blue at end point. The magnesium content was calculated by subtracting the value of calcium obtained from that of magnesium/calcium using the expression;

$$
\text { Magnesium content }(\mathrm{mg} / 100 \mathrm{~g})=\mathrm{Ca} / \mathrm{Mg}-\mathrm{Ca}
$$


Potassium (K) and sodium ( $\mathrm{Na}$ ) were determined with the aid of a flame photometer according to the method described by Oyeleke [14] with slight modifications. For the potassium and sodium determinations, $0.5 \mathrm{~cm}^{3}$ of sample extract was pipetted into a conical flask and diluted with distilled water. The flame photometer was calibrated at zero and at 100 ppm while aspirating the sample. The values obtained was used to plot a standard curve from which the concentration of potassium and sodium of the sample was extrapolated and multiplied by the dilution factor to obtain the actual concentration of potassium and sodium in the sample.

Phosphorus was determined using spectrophotometer followed by the method as described by Pearson [15] with slight modification. The concentration of phosphorus was determined spectrophotometrically at $660 \mathrm{~nm}$. The concentration of phosphorus was calculated using the equation:

$$
\text { Concentration of phosphorus }\left(\frac{\mathrm{mg}}{100 \mathrm{~g}}\right)=\frac{\text { Absorbance } \times \mathrm{CF} \times \mathrm{DF}}{\text { Atomic weight of Phosphorus }}
$$

Where: $\mathrm{CF}=$ conversion factor $=0.61$ and $\mathrm{DF}=$ dilution factor. All determination was performed in triplicate in each case.

\subsection{Statistical analysis}

Data were expressed in standard deviation (SD) and were analyzed using the statistical package for social sciences (SPSS) version 20 software package. Significance was accepted at $5 \%$ probability level. Significantly different means (P $<0.05$ ) were separated using the Least Significant Difference (LSD) method.

\section{Results and discussion}

\subsection{Phytochemicals composition}

The result of the phytochemical composition of Capsicum annum is shown in Table 1.

Table 1 Phytochemical composition of Capsicum annum

\begin{tabular}{lllllll}
\hline \multirow{2}{*}{ Drying method } & \multicolumn{5}{c}{ Phytochemicals (\%) } \\
\cline { 2 - 6 } & Alkaloid & Tannin & Saponin & Flavonoid & Anthraquinone & Polyphenol \\
\hline Open Sun Drying & $1.45 \pm 0.12$ & $1.42 \pm 0.21$ & $3.66 \pm 0.11$ & $0.54 \pm 0.05$ & $1.21 \pm 0.05$ & $3.20 \pm 0.13$ \\
Solar Drying & $1.23 \pm 0.11$ & $1.40 \pm 0.18$ & $3.26 \pm 0.10$ & $0.44 \pm 0.05$ & $1.19 \pm 0.03$ & $3.10 \pm 0.11$ \\
Control (Fresh) & $1.98 \pm 0.17$ & $1.72 \pm 0.24$ & $4.22 \pm 0.15$ & $1.52 \pm 0.02$ & $2.21 \pm 0.04$ & $4.18 \pm 0.14$ \\
\hline \multicolumn{7}{c}{ Values are expressed as mean \pm SEM for triplicate determinations, $\mathrm{n}=3$} \\
\end{tabular}

The results showed that the percentage all the analyzed phytochemicals is in the order fresh sample (control) $>0$ pen drying > Solar drying. The presence of tannins, flavonoids, alkaloids, saponins, anthraquinones and phenolic compounds is an indication of medicinal potentials of the pepper variety [16-17].

\subsection{Proximate analyses}

The result of the proximate composition of Capsicum annum is shown in Table 2. The level of moisture in vegetables is an indicative of the length of time which it could last before spoilage starts to set in. The high levels of moisture in the fresh sample compared to those subjected to open sun and solar drying methods suggests that the fresh pepper samples would not be store for long without spoilage since high water activity could enhance microbial action bringing about food spoilage. The lower moisture content found in both the open sun dried (2.67\%) and solar dried (5.83\%) samples is in agreement with the findings of Esayas et al., [18] who reported that dehydrating pepper increases the storage-life or shelf-life of peppers. The results however show that solar drying method is best for drying the sample if the desire is to prolong its storage-life. 
Table 2 Proximate composition of Capsicum annum

\begin{tabular}{lllllll}
\hline Drying method & \multicolumn{5}{c}{ Parameters (\%) } \\
\cline { 2 - 7 } & Moisture & Ash & $\begin{array}{l}\text { Crude } \\
\text { protein }\end{array}$ & Crude lipid & Crude fibre & $\begin{array}{l}\text { Total } \\
\text { carbohydrate }\end{array}$ \\
\hline Open Sun Drying & $5.83 \pm 0.57^{\mathrm{b}}$ & $10.67 \pm 1.89^{\mathrm{b}}$ & $4.67 \pm 0.16^{\mathrm{a}}$ & $1.33 \pm 0.29^{\mathrm{b}}$ & $18.33 \pm 0.76^{\mathrm{a}}$ & $62.33 \pm 1.76^{\mathrm{c}}$ \\
Solar Drying & $2.67 \pm 0.76^{\mathrm{c}}$ & $14.17 \pm 1.76^{\mathrm{a}}$ & $2.10 \pm 0.09^{\mathrm{b}}$ & $2.00 \pm 0.50^{\mathrm{a}}$ & $9.33 \pm 0.58^{\mathrm{b}}$ & $66.40 \pm 1.31^{\mathrm{b}}$ \\
Control (Fresh) & $93.00 \pm 1.80^{\mathrm{a}}$ & $5.50 \pm 0.50^{\mathrm{c}}$ & $2.03 \pm 0.14^{\mathrm{c}}$ & $0.83 \pm 0.29^{\mathrm{c}}$ & $0.67 \pm 0.29^{\mathrm{c}}$ & $90.94 \pm 0.90^{\mathrm{a}}$ \\
\hline
\end{tabular}

Values are means \pm standard deviation. Means with the letter(s) on the same row are not significantly different using the method of least significant difference (LSD) at 5\% probability.

The percentage ash content of the analyzed samples is in the order of solar drying > open-sun drying > fresh sample (control). The order of the percentage ash content corresponds to the percentage of minerals present notable calcium, sodium and phosphorus. This finding agrees with the reported findings made by other researchers [18, 19].

The low protein content of the dried samples compared to the control is an agreement with the report of Ejohet al., [19] which reported that pepper needs to be combined with other foods of high protein value in order to meet the protein requirements of individuals and the non-use of the pepper variety as sole ingredients to provide the basic protein need hence the need for supplementation with other protein condiments [20].

The low lipid content of the sample values agrees with the findings of many authors that red pepper is poor sources of lipids $[19,21]$.

Fibre has been reported to be essential in enhancing digestion and bowel movement [22]. While the sample exposed to solar drying has the highest percentage ash content than those exposed to sun drying, the fresh samples have the least ash content. This research is in agreement with the findings made by other researchers $[18,19]$.

The high levels of carbohydrate found in all samples analyzed might not be nutritionally assessable since most of them are bound to remain undigested in the body [21].

\subsection{Minerals content composition}

The result of the mineral analysis of Capsicum annum is shown in Table 3.

\begin{tabular}{llllll}
\hline Drying method & \multicolumn{5}{c}{ Parameters } \\
\cline { 2 - 6 } & $\begin{array}{l}\text { Calcium } \\
\mathbf{( m g / 1 0 0 g )}\end{array}$ & $\begin{array}{l}\text { Magnesium } \\
\mathbf{( m g / 1 0 0 g )}\end{array}$ & $\begin{array}{l}\text { Sodium } \\
\mathbf{( m g / 1 0 0 g )}\end{array}$ & $\begin{array}{l}\text { Potassium } \\
\mathbf{( m g / 1 0 0 g )}\end{array}$ & $\begin{array}{l}\text { Phosphorus } \\
\mathbf{( m g / 1 0 0 g )}\end{array}$ \\
\hline Open Sun Drying & $1.31 \pm 0.07^{\mathrm{b}}$ & $0.47 \pm 0.15^{\mathrm{c}}$ & $4.10 \pm 0.10^{\mathrm{b}}$ & $6.83 \pm 0.05^{\mathrm{a}}$ & $1.75 \pm 0.10^{\mathrm{c}}$ \\
Solar Drying & $1.38 \pm 0.13^{\mathrm{a}}$ & $2.90 \pm 0.13^{\mathrm{a}}$ & $7.87 \pm 0.15^{\mathrm{a}}$ & $5.47 \pm 0.25^{\mathrm{b}}$ & $1.83 \pm 0.34^{\mathrm{a}}$ \\
Control (Fresh) & $1.10 \pm 1.00^{\mathrm{c}}$ & $1.10 \pm 0.10^{\mathrm{c}}$ & $1.00 \pm 0.20^{\mathrm{c}}$ & $0.50 \pm 010^{\mathrm{c}}$ & $1.69 \pm 0.04^{\mathrm{b}}$
\end{tabular}

Values are means \pm SEM. Means with the letter(s) on the same row are not significantly different using the method of least significant difference (LSD) at $5 \%$ probability.

From the result of the elemental analysis, the Capsicum annum is a good source of calcium, magnesium, sodium, potassium and phosphorus hence can serve as a source of these micronutrients supplementation in diets. Sodium is an electrolyte which functions in the control of fluid balance in the body, controls extracellular fluid, and is essential for osmosis. It is important in maintaining acid-base balance in the body and participates in the transmission of nerve impulses essential for normal function [23]. Calcium, in combination with phosphorus, is a component of bones and teeth to give strength and hardness. Magnesium is an essential component of bone and cartilage. It also plays a role in enzyme activation and stimulates muscle and nerve irritability [24]. Dietary potassium may play a role in decreasing blood pressure. Potassium is involved in nerve function, muscle control and blood pressure [25]. The results of the elemental analysis is in agreement with several researches such as Ukegbu and Okereke, [26] who reported that dried vegetables has higher potassium content than fresh vegetables, Mongi, [27] who stated that drying improve the concentration of both organic and mineral constituents, Senem et al., [28] also stated that drying increased the magnesium and calcium content which could be as a result of increase in concentration of dry matter. 


\section{Conclusion}

The present study have established the quantitative phytochemical composition, proximate composition and minerals composition of Capsicum annum exposed to both open sun and solar drying methods respectively. The pepper variety contains substantial quantities of vital minerals, proximate parameters and phytochemicals in nutritional relevant quantity.

\section{Compliance with ethical standards}

\section{Acknowledgments}

The authors express their gratitude to Sokoto Energy Research Centre, Sokoto for availing us the opportunity to make use of their equipments for this study.

\section{Disclosure of conflict of interest}

The authors declare that they have no conflict of interests and are solely responsible for all the contents and writings presented in this research work.

\section{References}

[1] Bosland PW. (1993). Breeding for quality in Capsicum. Capsicum and Eggplant Newsletter, 12, 25-31.

[2] Ahmad F, Mohd YO, Mohd HR and Kamaruzzaman S. (2013). Drying of Malaysian Capsicum annuumL. (Red Chili) Dried by Open and Solar Drying. International Journal of Photoenergy, 21(2), 1 - 9.

[3] Dissa AO, Bathiebo J, Kam S, Savadogo PW, Desmorieux H and Koulidiati J. (2009). "Modelling and experimental validation of thin layer indirect solar drying of mango slices," Renewable Energy, 34(4), 1000-1008.

[4] Howard LR, Talcott ST, Brenes CH and Villalon B. (2000). Changes in phytochemical and antioxidant activity of selected pepper cultivars (Capsicum sp.) as influenced by maturity. Journal of Agriculture and Food Chemistry, 48(4), 1713-1720.

[5] Simonne AH, Simonne EH, Eitenmiller RR, Mills HA and Green NR. (1997). "Ascorbic acid and provitamin A contents in unusually colored bell peppers (Capsicum annuum L.)," Journal of Food Composition and Analysis, 10(4), 299-311.

[6] Guil-Guerrero JL, Mart'inez-Guirado C, Rebolloso-Fuentes MM and Carrique-P'erez A. (2006). "Nutrient composition and antioxidant activity of 10 pepper (Capsicum annuun) varieties," European Food Research Technology, 224(1), 1-9.

[7] Maxwell A, Seepersani MP and Mooton DR. (1995). 3, 6-Amino spirosoane steroid alkaloids from solamintriste. Journal of Natural Products, 58(4), 821-825.

[8] Bohn BA and Kocai-Abyaza R. (1994). Flavonoid and condensed from leaves of Hawaii Vaccinium ratulation and V. calycinum. Pacific Science, 48(1), 458-463.

[9] Makkar HPS and Becker K. (1996). Nutritional value and antinutritional components of whole and ethanol extracted Moringa oleifera. Animal Feed Science Technology, 63(3), 211-238.

[10] Trease GE and Evans WC. (1983). Pharmacognosy. 14th Edition. Brown Publication, London.

[11] Lawal A and Matazu SS. (2012). Proximate and Mineral Analysis of Allium sativum Cultivated in Sokoto area; Nigeria. Katsina Journal of Pure and Applied Sciences, 6(2): 14 - 20.

[12] Lawal A and Dangoggo S. (2014). Phytochemical, Proximate and Toxicity Studies of Aqueous Extract of Crinum ornatum (Toad's Onion). Chemsearch Journal, 5(1), 45 - 50.

[13] AOAC. (1990). Association of Official Analytical Chemist. Official Method of Analyst (15 th Ed), Washington DC, USA.

[14] Oyeleke AO. (1984). Outline of Food Analysis. Ahmadu Bello University Press, Zaria, Nigeria, 23-31.

[15] Pearson D. (1976). Chemical Analysis of Foods. $7^{\text {th }}$ Ed., Church Hill Livingstone, London, UK, 72-73, 138-143, 488496. 
[16] Salah W, Miller N, Pagauga G, Tybury G, Bolwell E, Rice E and Evans C. (1995). Flavonoids as scavenger of aqueous phase radicals and chain breaking antioxidants. Biochemistry Journal, 2(2), 239-346.

[17] Stray F. (1998). The natural guide to medicinal herbs and plants. Tiger Book International, London, 12-16.

[18] Esayas K, Shimelis A, Ashebir F, Tilahun B and Gulelat D. (2011). Proximate composition, Mineral content and Antinutritional factors of some capsicum (Capsicum annum) varieties grown in Ethiopia. Journal of Korean Society of Food Sciences and Nutrition, 37(8), 1084-1089.

[19] Ejoh AR, Tchouanguep MF and Fokou E. (1996). Nutrient composition of the leaves and flowers of Colocasia esculentaand the fruits of Solanum melongena. Plant Food for Human Nutrition, 49(2), 107-112.

[20] Christine EI, Peters H and Orim AO. (2014). Comparative evaluation of the nutritional, phytochemical and microbiological quality of three pepper varieties. Journal of Food and Nutritional Sciences, 2(3), 74-80.

[21] Gloria A, Oyelola B, Adenika T and Anthony J. (2010). Comparative analysis of the chemical composition of three spices. J. Korean Soc. Food Sci, Nut. 37(8): 1090-1095.

[22] Papas M, Giorannuli E and Platze E. (2004). Fibre from fruit and colorectal Neoplasia. Journal of Cancer Epidemiology and Biomedical Prevention, 13(3), 1267-1270.

[23] Onwuka GI. (2005). Food analysis and instrumentation theory and practice. 1st ed. Apex Book Limited, Lagos Nigeria, 63-120.

[24] Soetan KO, Olaiya CO and Oyewole OE. (2010). The Importance of Mineral Elements for Humans, Domestic Animals and Plants: A Review. African Journal of Food Sciences, 4(5), 200-222.

[25] Shosy SO. (2015). Effect of Varieties of and Drying Methods on Nutrient Content and Sensory Acceptability of Processed Products from "Mamung'unya" (Benincasahispida). Master Thesis, University of Agriculture, Morogoro, Tanzania. 112-134.

[26] Ukegbu PO and Okereke CJ. (2013). Effect of Solar and Sun Drying methods on the Nutrients Composition and Microbial Load in Selected Vegetables, African Spinach (Amaranthus hybridus), Fluted Pumpkin (Telferia occidentalis) and Okra (Hibiscus esculentus). Sky Journal of Food Sciences, 2(5), 35-40.

[27] Mongi RJ. (2013). Solar Drying of Fruits and Vegetables: Dryers' Thermal Performance, Quality and Shelf Life of Dried Mango, Banana, Pineapple and Tomato. PhD Thesis. University of Agriculture, Morogoro, Tanzania. 132141.

[28] Senem S, Canan E, Bige I, Glusah, O and Omer U. (2014). Impact of Drying Methods on Physicochemical and Sensory Properties of Apricot pestil. Indian Journal of Traditional Knowledge, 13 (1), 47-55.

\section{How to cite this article}

Tambuwal AD, Okoh EVC, Ogbiko C and Maishanu MS. (2018). Comparative evaluation of the phytochemical, proximate and mineral quality of Nigerian Capsicum annum exposed to open and solar drying. GSC Biological and Pharmaceutical Sciences, 5(2), 139-144. 